\title{
Milk protein addition to a post-exercise carbohydrate-electrolyte rehydration solution. Is there a dose-response relationship?
}

\author{
L. J. James, R. Harris, J. Madin, D. Scott, M. Stepney, R. Stone and D. J. Clayton \\ Sport, Health and Performance Enhancement (SHAPE) Research Group, School of Science and Technology, \\ Nottingham Trent University, Nottingham NG11 8NS, UK
}

The ingestion of low-fat milk has been shown to be more effective at restoring fluid balance after exercise-induced dehydration than the ingestion of a commercially available carbohydrate-electrolyte sports drink ${ }^{(1)}$. More recently, it has been shown that after exerciseinduced dehydration, the inclusion of $25 \mathrm{~g} / 1$ milk protein in a carbohydrate-electrolyte rehydration solution increased drink retention in comparison with an isoenergetic, electrolyte content matched carbohydrate solution ${ }^{(2)}$. This suggests that the protein present in milk $(\sim 36 \mathrm{~g} / \mathrm{l})$ accounts for at least some of the increased drink retention previously reported. It is currently unknown whether there is a doseresponse effect of milk protein on drink retention after exercise-induced dehydration. The aim of the present study was to investigate this.

Eight males [mean (SD): age 22 (SD 2) years, height 1.77 (SD 0.08) m, body mass $76.96(\mathrm{SD} 8.73) \mathrm{kg}$ ] completed intermittent exercise in a hot environment [35.0(SD 0.1$)^{\circ} \mathrm{C}, 51.8$ (SD 5.9) relative humidity] until they lost 1.83 (SD 0.10$) \%$ of their initial body mass. Subjects then ingested a volume of drink in litres equivalent to $150 \%$ of their body mass loss in $\mathrm{kg}$. This drink was provided in four aliquots of equal volume at $15 \mathrm{~min}$ intervals $(0,15,30$ and $45 \mathrm{~min})$ over a $1 \mathrm{~h}$ rehydration period. Subjects then remained in the laboratory for a further $4 \mathrm{~h}$. During each trial, subjects consumed one of the three drinks: a $60 \mathrm{~g} / \mathrm{l}$ carbohydrate solution (C); a $40 \mathrm{~g} / \mathrm{l}$ carbohydrate, $20 \mathrm{~g} / \mathrm{l}$ milk-protein solution (CP20); or a $20 \mathrm{~g} / \mathrm{l}$ carbohydrate, $40 \mathrm{~g} / \mathrm{l}$ milk-protein solution (CP40). Drinks were matched in terms of energy density, as well as $\mathrm{Na}(\sim 20 \mathrm{mmol} / \mathrm{l})$ and $\mathrm{K}(\sim 5 \mathrm{mmol} / \mathrm{l})$ content. Urine samples were collected before and after exercise, after rehydration and every hour during the $4 \mathrm{~h}$ recovery period. Urine samples were measured for volume, osmolality and $\mathrm{Na}$ and $\mathrm{K}$ concentration. Trials were administered in a double blind, randomised crossover design.

Total cumulative urine output after rehydration was greater for trial C [1150(sD 245) $\mathrm{ml}$ ] than for trial CP20 [857(SD 270) $\mathrm{ml}]$ $(P=0.007)$ and CP40 [769(sD 129) ml] $(P=0.006)$, with no difference between CP20 and CP40 $(P=1.000)$. As a result, total drink retention was greater for CP20 [58(SD 9)\%] $(P=0.002)$ and CP40 [64(SD 7)\%] $(P<0.001)$ than C [43(SD 7\%] $(P=0.008)$, but there was no difference between $\mathrm{CP} 20$ and CP40 $(P=1.000)$. At the end of the study period, whole-body net-fluid balance (estimated from fluid lost through sweat and urine production and fluid gained through drink ingestion) was less negative for trials CP20 [-203(SD 315) ml] $(P=0.029)$ and CP40 [ $-97($ SD 146$)] 1)(P=0.001)$ than for trial C $[-487($ SD 149$) \mathrm{ml}]$, but there was no difference between CP20 and $\mathrm{CP} 40(P=1.000)$. Although the mean net-fluid balance was negative for all trials at the end of the study, it was only significantly negative after ingestion of drink $\mathrm{C}(P=0.002)$.

This study further demonstrates that after exercise-induced dehydration, a carbohydrate-milk protein solution is better retained than a carbohydrate solution, when solutions are matched in terms of energy density, as well as $\mathrm{Na}$ and $\mathrm{K}$ content. The results also suggest that there is no dose-response relationship between milk-protein ingestion and drink retention after exercise-induced dehydration, at least in the concentrations of milk protein used in this study.

1. Shirreffs SM, Watson P \& Maughan RJ (2007) Br J Nutr 98, 173-180.

2. James LJ, Clayton D \& Evans GH (2011) Br J Nutr 105, 393-399. 